Article

\title{
Euryops pectinatus L. Flower Extract Inhibits P-glycoprotein and Reverses Multi-Drug Resistance in Cancer Cells: A Mechanistic Study
}

\author{
Wafaa M. Elkady ${ }^{1}{ }^{\circledR}$, Iriny M. Ayoub ${ }^{2, *}\left(\mathbb{D}\right.$, Yousra Abdel-Mottaleb ${ }^{3}{ }^{\circledR}$, Mohamed F. ElShafie ${ }^{4,5}$ \\ and Michael Wink ${ }^{6, *(D)}$ \\ 1 Department of Pharmacognosy, Faculty of Pharmaceutical Sciences and Pharmaceutical Industries, \\ Future University in Egypt, New Cairo 11835, Egypt; welkady@fue.edu.eg \\ 2 Department of Pharmacognosy, Faculty of Pharmacy, Ain Shams University, Cairo 11566, Egypt \\ 3 Department of Pharmacology, Toxicology and Biochemistry, Faculty of Pharmaceutical Sciences \\ and Pharmaceutical Industries, Future University in Egypt, New Cairo 11835, Egypt; \\ yabdelmottaleb@gmail.com \\ 4 Department of Pharmacology and Toxicology, Faculty of Pharmacy, Al-Azhar University, Cairo 11884, Egypt; \\ mohamed.elshfie@su.edu.eg \\ 5 Department of Pharmacology and Toxicology, Faculty of Pharmacy, Sinai University, \\ East Kantara-New City, El Ismailia 41636, Egypt \\ 6 Institute of Pharmacy and Molecular Biotechnology, Heidelberg University, INF 364, \\ D-69120 Heidelberg, Germany \\ * Correspondence: irinyayoub@pharma.asu.edu.eg (I.M.A.); wink@uni-heidelberg.de (M.W.); \\ Tel.: +20-12-2141-6070 (I.M.A.); Fax: +49-62-21-54-48-84 (M.W.)
}

Academic Editors: Anna Andolfi and Maria Michela Salvatore Received: 18 January 2020; Accepted: 1 February 2020; Published: 3 February 2020

\begin{abstract}
Euryops pectinatus is a South African ornamental plant belonging to family Asteraceae. The present work evaluates the cytotoxic activity and phytochemical profile of the flower extract. Metabolite profiling was performed using HPLC-PDA-ESI-MS/MS. Total phenolics and flavonoids content were assessed. Cytotoxicity was evaluated against 6 different cancer cell lines using MTT assay. The possible underlying mechanism was proposed. We analyzed whether the extract could overcome the resistance of multidrug-resistant cancer cells for doxorubicin. The effect of combination of E. pectinatus with doxorubicin was also studied. Additionally, the potential inhibitory activity of the identified phytochemicals to PB1 protein was analyzed using in silico molecular docking. Twenty-five compounds were tentatively identified. Total phenolic and flavonoid contents represented $49.41 \pm 0.66$ and $23.37 \pm 0.23 \mu \mathrm{g} / \mathrm{mg}$ dried flower extract, respectively. The extract showed selective cytotoxicity against $\mathrm{Caco} 2$ cells but its main effect goes beyond mere cytotoxicity. It showed strong inhibition of P-glycoprotein, which helps to overcome multidrug resistance to classical chemotherapeutic agents. In silico molecular docking showed that dicaffeoyl quinic acid, kaempferol-O-rutinoside, rutin, and isorhamnetin-O-rutinoside exhibited the most potent inhibitory activity to PB1 involved in tumor progression. Euryops pectinatus flower heads could have promising selective cytotoxicity alone or in combination with other chemotherapeutic agents to counteract multidrug resistance.
\end{abstract}

Keywords: Euryops pectinatus; LC/MS; cytotoxicity; P-glycoprotein; multidrug resistance; bromodomains; molecular docking

\section{Introduction}

The development of drug resistance during cancer chemotherapy limits the survival rate of cancer patients [1]. Multidrug resistance (MDR) renders cancer cells immune to standard treatments 
with various anti-cancer drugs and is a major limitation of cancer therapy [2]. To overcome MDR in cancer treatment, many strategies have been proposed, including chemotherapy with a combination of anti-tumor drugs and an inhibitor of P-glycoprotein (P-gp) and other $\mathrm{ABC}$ transporters. P-gp belongs to the first member of the ATP-binding cassette $(A B C)$ superfamily, which is encoded by the MDR1 gene [2], and is widely expressed in epithelial cells of normal tissues that are involved in drug disposition, including the liver, intestine, and kidney. It has been reported that P-gp and other $\mathrm{ABC}$ transporter can actively bind and pump out drugs against the concentration gradient by an ATP-powered membrane drug efflux pump; therefore, anticancer drugs are prevented from accumulation inside the cells to trigger cytotoxic effects. The intracellular concentration of some commonly used anticancer drugs is reduced by $\mathrm{P}$-gp and other $\mathrm{ABC}$ transporter, including vincristine, etoposide, and doxorubicin [3]. The first generation of P-gp inhibitors included verapamil, trifluoperazine, cyclosporine-A, quinidine, reserpine, vincristine, yohimbine, tamoxifen, and toremifene, which are all competitive substrates of P-glycoprotein [3]. Natural compounds isolated from medicinal plants are promising leads in the development of novel chemotherapeutic agents [4].

Euryops pectinatus (L.) Cass (Asteraceae) is native to South Africa and is widely used as an ornamental plant. It is commonly known as woolly resin bush, golden daisy bush or golden Euryops [5]. The genus name is from the Greek eurys, meaning 'large' and ops, meaning 'eye', referring to its showy flowers. The species name pectinatus, is Latin meaning 'pectinate' with narrow divisions like a comb, denoting the divided leaves [5]. Flavonoids, furoeremophilanes, eremophilanolides, and secofuroeremophilanes were identified from the genus Euryops [6]. Essential oil of E. arabicus leaves was rich in sesquiterpene hydrocarbons and oxygenated sesquiterpenes [7]. The hexane extract of E. pectinatus flower-heads was dominated by $n$-pentacosane in addition to phytosterols in the unsaponifiable fraction, whereas, linoleinic acid was the major constituent in the saponifiable fraction [8]. Another species, E. arabicus displayed in vivo antioxidant and protective effects against hepatorenal toxicity induced by paracetamol in rats [6]. E. pectinatus leaf essential oil displayed potent in vitro cytotoxic activity against Ehrlich ascites carcinoma cells (EAC) and human brain cells (U251) [9].

Only few phytochemical and pharmacological reports have been published from E. pectinatus. In this context, this study aimed to evaluate the metabolic profile and anti-proliferative activity of E. pectinatus flower heads. The possible underlying mechanism of action was also evaluated. Moreover, the inhibitory activity of the identified phytochemicals to PB1 protein involved in tumour progression was investigated using in silico molecular docking.

\section{Results and Discussion}

\subsection{Phytochemical Analysis}

\subsubsection{Quantitation of Total Phenolic and Flavonoid Content}

Quantitative analysis of the EP-MF revealed the presence of considerable amount of both phenolic and flavonoid constituents; $49.41 \pm 0.66 \mu \mathrm{g} / \mathrm{mg}$ and $23.37 \pm 0.23 \mu \mathrm{g} / \mathrm{mg}$ dried flower extract respectively.

\subsubsection{Metabolites Profiling of E. pectinatus Flower Heads Methanolic Fraction}

A comprehensive metabolic profiling of the EP-MF was performed using HPLC-PDA-ESI-MS/MS. Chromatograms were acquired in both negative and positive ion modes (Figure 1). A total of 29 peaks were detected, of which 25 metabolites were tentatively identified based on their UV spectra as well as MS/MS data given by the mass of the molecular ion peak and their fragments, considering the neutral mass loss and known fragmentation patterns as well as comparison with the available literature. A list of identified peaks together with their chromatographic and spectroscopic data is presented in Table 1. The identified compounds belonged to various classes, including organic acids, phenolic acids, flavonoids and fatty acids. 


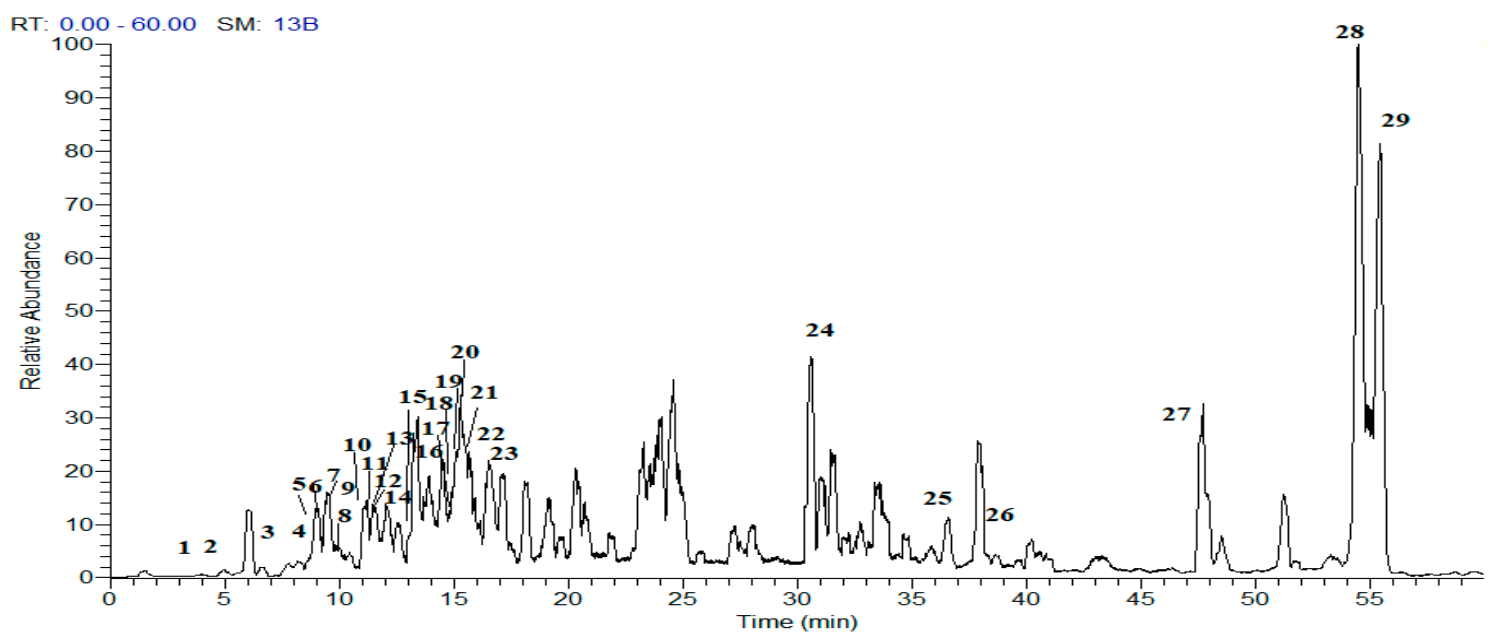

Figure 1. HPLC-ESI-MS base peak chromatogram of E. pectinatus flower heads in the negative ion mode. Peak numbers correspond to compounds listed in Table 1.

Phenolic Acids and Their Derivatives

In the present work, fourteen phenolic acids were characterized from EP-MF, mainly, caffeic acid, quinic acid, protocatechuic acid and sinapic acid derivatives. Peak 3 exhibited a deprotonated molecular ion at $m / z 153$, and a product ion at $m / z 109$ via the loss of $\mathrm{CO}_{2}$. Thus, peak 3 could be annotated as protocatechuic acid [10]. Chlorogenic acid could be detected at $8.35 \mathrm{~min}$ (Peak 4), where it showed $[\mathrm{M}-\mathrm{H}]^{-}$at $m / z 353$ and $\mathrm{MS}^{2}$ ions at $m / z 191$ (quinic acid) and $m / z 179$ (caffeic acid).

Peaks 10 and 12 showed quasi molecular ion peaks at $m / z 367$ and exhibited a product ion at $\mathrm{m} / \mathrm{z}$ 191 indicating a quinic acid moiety, following the loss of a ferulic acid moiety. Thus, peaks 10 and 12 could be identified as feruloyl quinic acid isomers [11,12]. Peak 11 was identified as caffeic acid, where it showed a molecular ion peak at $\mathrm{m} / \mathrm{z} 179$ with a product ion at $\mathrm{m} / \mathrm{z} 135$ owing to the loss of $\mathrm{CO}_{2}[12,13]$. Meanwhile, caffeic acid-O-hexoside (peak 5) exhibited a parent ion at $\mathrm{m} / \mathrm{z} 341$ and a fragment ion at $\mathrm{m} / \mathrm{z}$ 179 for caffeic acid corresponding the loss of a hexose moiety ( $-162 \mathrm{amu}$ ) [13]. Peaks 7 and 8 exhibited deprotonated molecular ions at $\mathrm{m} / \mathrm{z} 353$ and were assigned as caffeoyl quinic acid isomers. Both compounds displayed similar fragmentation pattern showing product ions in the MS/MS spectrum at $m / z 191$ corresponding to quinic acid moiety and a fragment ion at $m / z 179$ suggesting a caffeic acid moiety. Peak 13 showed a parent ion at $m / z 223$ and MS ${ }^{2}$ fragments at $m / z 179$ resulting from the loss of a $\mathrm{CO}_{2}$ fragment thus suggesting a carboxylic acid, followed by a subsequent loss of a methyl group at $m / z$ 165. Therefore, peak 13 was tentatively identified as sinapic acid [14,15].

\section{Flavonol Glycosides}

Quercetin, kaempferol, isorhamnetin and syringetin glycosides were the major flavonol glycosides identified in E. pectinatus flower heads; quercetin-O-glycosides such as quercetin-3-O-hexoside and quercetin-3-O-rutinoside (rutin) showed characteristic product ion at $\mathrm{m} / \mathrm{z} 301$, corresponding to quercetin aglycone [16]. The nature of the sugars could be revealed by elimination of the sugar residue, that is, $162 \mathrm{amu}$ (hexose; glucose or galactose) and $146 \mathrm{amu}$ (rhamnose) [17]. A kaempferol $\mathrm{O}$-glycoside namely, kaempferol-O-rutinoside (18), showed a deprotonated molecular ion at $\mathrm{m} / \mathrm{z}$ 593 and a product ion at $\mathrm{m} / \mathrm{z} 285$, corresponding to kaempferol aglycone following the loss of $308 \mathrm{amu}$ (a rutinose) [16]. Additionally, peaks 22 and 23 were tentatively identified as isorhamnetin glycosides; namely, isorhamnetin-O-rutinoside and isorhamnetin-O-hexoside exhibiting molecular ion peaks at $m / z 623$ and 477, respectively. Both exhibited a characteristic product ion at $\mathrm{m} / \mathrm{z} 315$, corresponding to isorhamnetin aglycone, and a loss of 308 (rutinose) and 162 (hexose), respectively [16]. Syringetin-O-hexoside (Peak 14) followed the same fragmentation manner, exhibiting a molecular ion peak at $\mathrm{m} / \mathrm{z} 507$ and a characteristic fragment ion at $\mathrm{m} / \mathrm{z} 345$ corresponding to syringetin aglycone 
and the loss of 162 amu of a hexose moiety. The respective molecular weights were recorded in Table 1 and the fragmentation pattern is illustrated in Figures S1-S12 (Supplementary Materials).

Table 1. Metabolites assigned in E. pectinatus flower heads using HPLC-PDA-ESI-MS/MS in negative ion mode.

\begin{tabular}{|c|c|c|c|c|c|c|c|}
\hline & Compound & $R t$ (min) & {$[\mathbf{M}-\mathbf{H}]^{-}$} & Fragment Ions & $\begin{array}{l}\text { UV-vis } \\
\left(\lambda_{\max } \mathrm{nm}\right)\end{array}$ & Class & References \\
\hline 1 & Malic acid & 4.05 & 133 & 115,99 & 261 & Organic acid & \\
\hline 2 & Cinnamic acid & 4.15 & 147 & 129,115 & 261 & Phenolic acid & \\
\hline 3 & Protocatechuic acid & 6.61 & 153 & 109 & 257,290 & Phenolic acid & [10] \\
\hline 4 & Chlorogenic acid & 8.35 & 353 & 191,179 & 319,379 & Phenolic acid & [11] \\
\hline 5 & Caffeic acid-O-hexoside & 8.99 & 341 & 179,135 & 319 & Phenolic glycoside & {$[12,13]$} \\
\hline 6 & Quinic acid & 9.14 & 191 & $173,127,111$ & 216,323 & Organic acid & [10] \\
\hline 7 & Caffeoyl quinic acid & 9.48 & 353 & 191,179 & 324 & Phenolic acid & [17] \\
\hline 8 & Caffeoyl quinic acid (isomer) & 9.90 & 353 & 191,179 & 324 & Phenolic acid & [17] \\
\hline 9 & Caffeoyl quinic acid dimer & 9.57 & 707 & $\begin{array}{l}645,514,456 \\
353\end{array}$ & 290,322 & Phenolic acid & \\
\hline 10 & Feruloyl quinic acid & 11.04 & 367 & 191,173 & 295,322 & Phenolic acid & {$[11,12]$} \\
\hline 11 & Caffeic acid & 11.18 & 179 & 135 & 297,324 & Phenolic acid & {$[12,13]$} \\
\hline 12 & Feruloyl quinic acid isomer & 11.47 & 367 & 191,173 & 295,322 & Phenolic acid & {$[11,12]$} \\
\hline 13 & Sinapic acid & 11.59 & 223 & $205,179,163$ & 296,341 & Phenolic acid & {$[14,15]$} \\
\hline 14 & Syringetin-3-O-hexoside & 12.15 & 507 & 345 & 289,325 & Flavonol glycoside & {$[18]$} \\
\hline 15 & Dicaffeoyl quinic acid hexoside & 13.09 & 677 & 516 & 289,324 & Phenolic glycoside & \\
\hline 16 & Caffeoyl malonylhexoside & 13.79 & 427 & $\begin{array}{l}409,265,179 . \\
135\end{array}$ & 291,324 & Phenolic glycoside & \\
\hline 17 & Dicaffeoyl quinic acid & 14.56 & 515 & $\begin{array}{c}515,353,191 \\
179\end{array}$ & $\begin{array}{l}253,300 \\
333\end{array}$ & Phenolic acid & [13] \\
\hline 18 & Kaempferol-O-rutinoside & 14.84 & 593 & 431,285 & 253,332 & Flavonol glycoside & [16] \\
\hline 19 & Dicaffeoyl quinic acid & 14.94 & 515 & $353,191,179$ & $\begin{array}{l}253,300 \\
333\end{array}$ & Phenolic acid & \\
\hline 20 & Quercetin-3-O-rutinoside (Rutin) & 15.23 & 609 & 343,301 & 254,348 & Flavonol glycoside & [19] \\
\hline 21 & Quercetin-3-O-hexoside & 15.43 & 463 & 301 & 255,351 & Flavonol glycoside & {$[19,20]$} \\
\hline 22 & Isorhamnetin-O-rutinoside & 16.52 & 623 & $315,300,255$ & $\begin{array}{l}253,292 \\
338\end{array}$ & Flavonol glycoside & [20] \\
\hline 23 & Isorhamnetin-3-O-hexoside & 17.20 & 477 & 315,314 & 288,336 & Flavonol glycoside & [16] \\
\hline 24 & Unidentified & 30.66 & 344 & 258,226 & 282 & Unknown & \\
\hline 25 & Unidentified & 36.57 & 507 & $\begin{array}{l}407,283,231 \\
153\end{array}$ & 279 & Unknown & \\
\hline 26 & Hydroxy-octadecadienoic acid & 38.73 & 295 & 295,277 & 282 & Fatty acid & [17] \\
\hline 27 & Hydroxyhexadecanoic acid & 47.66 & 271 & $\begin{array}{c}271,254,242, \\
226\end{array}$ & 277 & Fatty acid & [17] \\
\hline 28 & Unidentified & 54.56 & 817 & $\begin{array}{l}577,559,538 \\
443,317,285\end{array}$ & 279 & Unknown & \\
\hline 29 & Unidentified & 55.42 & 815 & $\begin{array}{l}785,733,606 \\
560,538,483 \\
415,278,235\end{array}$ & 275 & Unknown & \\
\hline
\end{tabular}

\subsection{Cytotoxicity of E. pectinatus Using MTT Assay}

Cytotoxicity of the extract was evaluated on 6 different cancer cell lines in comparison to two standard drugs: doxorubicin and 5-fluorouracil (Table 2). In general, EP-MF shows moderate cytotoxicity. Results showed that EP-MF exhibited higher cytotoxicity against Caco-2 $\left(\mathrm{IC}_{50}=\right.$ $17.04 \mu \mathrm{g} / \mathrm{mL}$ ) compared to 5-fluorouracil ( $\mathrm{IC}_{50}=20.22 \mu \mathrm{g} / \mathrm{mL}$ ).

Table 2. Cytotoxicity of E. pectinatus using MTT assay.

\begin{tabular}{ccccccc}
\hline $\begin{array}{c}\text { Drug IC } \\
(\boldsymbol{\mu g} / \mathbf{m L})\end{array}$ & MCF-7 & HepG2 & A549 & Caco-2 & HCT-116 & CCRF-CEM \\
\hline Doxorubicin & 0.44 & 0.977 & 5.842 & 8.508 & 6.87 & 0.033 \\
5-Fluorouracil & 1.71 & 4.12 & 10.32 & 20.22 & 18.33 & 1.22 \\
E.pectinatus-MF & 23.32 & 16.15 & 52.12 & 17.04 & 31.55 & 28.76 \\
\hline
\end{tabular}

2.2.1. $\mathrm{IC}_{50}$ Values and Relative Resistance of Doxorubicin and EP-MF in Wild-type and Multidrug-resistant MCF-7/Dox, CEM/ADR5000 Leukemia Cells

As expected, the $\mathrm{IC}_{50}$ values of doxorubicin and EP-MF in the MDR cell lines MCF7/Dox and CEM/ADR5000 (Table 3A/B) were higher than in the sensitive parent cell lines (Table 3A/B). 
Table 3. $\mathrm{IC}_{50}$ and relative resistance values of doxorubicin and EP-MF (A) in MCF-7 and multidrug-resistant MCF-7/Dox. (B) in CCRF-CEM and multidrug-resistant CEM/ADR5000 cells.

\begin{tabular}{|c|c|c|c|}
\hline A. Drug & $\begin{array}{c}\text { MCF-7 } \\
\mathrm{IC}_{50}(\mu \mathrm{g} / \mathrm{mL}) \\
\text { Mean } \pm \mathrm{SE}\end{array}$ & $\begin{array}{c}\text { MCF-7/Dox } \\
\mathrm{IC}_{50}(\mu \mathrm{g} / \mathrm{mL}) \\
\text { Mean } \pm \mathrm{SE}\end{array}$ & Relative Resistance \\
\hline Doxorubicin & $0.44 \pm 0.032$ & $16.82 * \pm 1.12$ & 38.23 \\
\hline E. pectinatus-MF & $23.32^{\mathrm{a}} \pm 1.52$ & $65.92^{a, *} \pm 3.78$ & 2.83 \\
\hline B. Drug & $\begin{array}{l}\text { CCRF-CEM } \\
\mathrm{IC}_{50} \mu \mathrm{g} / \mathrm{mL} \\
\text { Mean } \pm \mathrm{SE}\end{array}$ & $\begin{array}{l}\text { CEM/ADR5000 } \\
\text { IC }_{50} \mu \mathrm{g} / \mathrm{mL} \\
\text { Mean } \pm \mathrm{SE}\end{array}$ & Relative Resistance \\
\hline Doxorubicin & $0.033 \pm 0.006$ & $4.57^{*} \pm 0.41$ & 138.48 \\
\hline E. pectinatus-MF & $28.76^{a} \pm 1.86$ & $97.42^{\mathrm{a}, *} \pm 4.36$ & 3.39 \\
\hline
\end{tabular}

Data are presented as means $\pm \mathrm{SE}, n=4$. Cells were incubated for $72 \mathrm{~h}$. MTT assay was used for assessment of cytotoxicity. Relative resistance is calculated as the degree of drug resistance $\left(\mathrm{IC}_{50}\right.$ of MCF-7/Dox divided by $\mathrm{IC}_{50}$ of MCF-7 and IC $_{50}$ of CEM/ADR5000 divided by IC $_{50}$ of CCRF-CEM)). a: Significantly different from doxorubicin at $p<0.05$ using one-way analysis of variance (ANOVA) followed by Dunnett as post-hoc test. *: Significantly different from MCF-7 at $p<0.05$ using unpaired Student's $t$-test in Table 3A and *: Significantly different from CCRF-CEM leukemia cells at $p<0.05$ using unpaired Student's t-test in Table 3B.

\subsubsection{Effects of Combinations of EP-MF and Doxorubicin}

The $\mathrm{IC}_{50}$ values of doxorubicin alone and in combination with EP-MF in MDR CEM/ADR5000 and Caco-2 cells were calculated and represented in Table 4. The combination of EP-MF $(5 \mu \mathrm{g} / \mathrm{mL})$ with DOX has increased the potency by almost $50 \%$ in MCF/Dox cells and CEM/ADR500 cells, and by $37 \%$ in Caco2 cells, approximately.

Table 4. Effects of EP-MF on doxorubicin cytotoxicity in MCF-7/Dox, CEM/ADR5000, and Caco-2 cells.

\begin{tabular}{cccc}
\hline & $\begin{array}{c}\text { MCF-7/Dox } \\
\mathrm{IC}_{\mathbf{5 0}}(\mu \mathrm{g} / \mathbf{m L}) \\
\text { Mean } \pm \mathrm{SE}\end{array}$ & $\begin{array}{c}\text { CEM/ADR5000 } \\
\mathrm{IC}_{\mathbf{5 0}}(\mu \mathrm{g} / \mathbf{m L}) \\
\text { Mean } \pm \mathrm{SE}\end{array}$ & $\begin{array}{c}\text { Caco-2 cells } \\
\mathrm{IC}_{\mathbf{5 0}}(\mu \mathrm{g} / \mathrm{mL}) \\
\text { Mean } \pm \mathrm{SE}\end{array}$ \\
\hline Doxorubicin & $16.82 \pm 1.12$ & $4.57 \pm 0.41$ & $8.50 \pm 0.65$ \\
DOX + E. pectinatus-MF & $7.64^{\mathrm{a}} \pm 0.54$ & $2.18^{\mathrm{a}} \pm 0.22$ & $5.28^{\mathrm{a}} \pm 0.73$ \\
\hline
\end{tabular}

Data are presented as means $\pm \mathrm{SE}, n=4$. Cells were incubated with $E$. pectinatus for $6 \mathrm{~h}$, then followed by doxorubicin thereafter for $72 \mathrm{~h}$. ${ }^{\text {a: }}$ Significantly different from doxorubicin at $p<0.05$ using one-way analysis of variance (ANOVA) followed by Dunnett as post-hoc test.

\subsubsection{Effects of the Extract on P-glycoprotein Activity in CEM/ADR5000 Cells and in Caco-2 Cells}

To further investigate the effects shown in Tables 3 and 4, the inhibition of P-pg by verapamil as a standard drug and EP-MF were assessed in the calcein AM assay (Table 5). The extract had a similar inhibitory activity as verapamil. With regard to the presence of quercetin and rutin in the extract (Table 1), one can speculate about these promising effects. Earlier studies have shown similar effects regarding inhibition of $\mathrm{P}$-glycoprotein by quercitin and rutin, which are considered potential chemosensitizing agents to overcome MDR in cancer. Indeed, there exist a long line of P-glycoprotein inhibitors however, their use is limited by their toxicity and their wide drug interactions. On the other hand, up to $10 \mu \mathrm{M}$ of quercitin and rutin are well tolerated by patients presenting an excellent potential to overcome MDR in cancer [21].

\subsection{Molecular Docking}

Bromodomains have attracted serious interest over the past few years as promising new epigenetic targets for diverse human diseases as cancer. PB1 protein is considered a critical factor for tumor progression [22]. The inhibitory activity of the identified metabolites from our extract to the PB1 protein was evaluated using in silico molecular docking. The crystal structure of luteolin extracted from PB-1 
was superimposed to the docked pose and agreed well with the conformation obtained, leading to an RMSD value between the calculated pose and the crystal structure of 1.9445 .

Table 5. Effects of E. pectinatus-MF on intracellular calcein fluorescence in CEM/ADR5000 cells and Caco2 cells.

\begin{tabular}{|c|c|c|c|c|}
\hline \multirow{3}{*}{ Compound } & \multicolumn{4}{|c|}{$\begin{array}{c}\text { CEM/ADR5000 } \\
\text { Intracellular Calcein Fluorescence (\% Control) Mean } \pm \text { SE }\end{array}$} \\
\hline & \multicolumn{4}{|c|}{ Concentration } \\
\hline & $0.5 \mu \mathrm{g} / \mathrm{mL}$ & $2.5 \mu \mathrm{g} / \mathrm{mL}$ & $5 \mu \mathrm{g} / \mathrm{mL}$ & $10 \mu \mathrm{g} / \mathrm{mL}$ \\
\hline Control & $100 \pm 0$ & $100 \pm 0$ & $100 \pm 0$ & $100 \pm 0$ \\
\hline Verapamil & $100.54 \pm 4.24$ & $167.63^{a} \pm 9.41$ & $268.24^{\mathrm{a}} \pm 11.42$ & $324.4^{a} \pm 18.71$ \\
\hline E. pectinatus-MF & $102.01 \pm 6.82$ & $162.54^{\mathrm{a}} \pm 10.82$ & $284.63^{\mathrm{a}} \pm 21.42$ & $296.9^{a} \pm 12.05$ \\
\hline \multirow{3}{*}{ Compound } & \multicolumn{4}{|c|}{$\begin{array}{c}\text { Caco-2 } \\
\text { Intracellular Calcein fluorescence (\% Control) Mean } \pm \mathrm{SE}\end{array}$} \\
\hline & \multicolumn{4}{|c|}{ Concentration } \\
\hline & $0.5 \mu \mathrm{g} / \mathrm{mL}$ & $2.5 \mu \mathrm{g} / \mathrm{mL}$ & $5 \mu \mathrm{g} / \mathrm{mL}$ & $10 \mu \mathrm{g} / \mathrm{mL}$ \\
\hline Control & $100 \pm 0$ & $100 \pm 0$ & $100 \pm 0$ & $100 \pm 0$ \\
\hline Verapamil & $103.71 \pm 8.67$ & $165.63^{a} \pm 13.78$ & $220.25^{\mathrm{a}} \pm 11.12$ & $304.13^{a} \pm 12.55$ \\
\hline E. pectinatus-MF & $103.67 \pm 7.01$ & $173.92^{\mathrm{a}} \pm 13.86$ & $221.74^{a} \pm 20.17$ & $288.22^{a} \pm 16.64$ \\
\hline
\end{tabular}

Data are presented as means $\pm \mathrm{SE}, n=6$. CEM/ADR5000 cells were incubated for $1.5 \mathrm{~h}$. Calcein-AM assay was achieved using Flowcytometry. ${ }^{\text {a: }}$ Significantly different from control at $p<0.05$ using one-way analysis of variance (ANOVA) followed by Dunnett as post-hoc test. Caco-2 cells were incubated for $2 \mathrm{~h}$. Calcein-AM assay was achieved using a Fluoroskan Ascent plate reader. ${ }^{a}$ : significantly different from control at $p<0.05$ using one way analysis of variance (ANOVA) followed by Dunnett as post-hoc test.

The ability of the tested phytochemicals to interact with the key amino acids through H-bonding and $\pi-\pi$ stacking with different amino acids in the binding site of PB1 receptor rationalizes their efficiency in cytotoxic activity as indicated by their docking pattern and docking score with PB1 receptor protein compared to that of luteolin, the co-crystallized ligand (ca. $-35.38 \mathrm{Kcal} / \mathrm{mol}$ ). Dicaffeoyl quinic acid isomers (17 and 19), quercetin-O-hexoside (21), kaempferol-O-rutinoside (18), rutin (20), isorhamnetin-O-rutinoside (22), feruloyl quinic acid isomers (10 and 12), caffeoyl quinic acid isomers (7 and 8) showed the most potent inhibitory activities compared to luteolin as represented by their favorable binding exhibiting high free binding energies to $\mathrm{Pb} 1$ active site. The binding energy and pattern for each compound is represented in (Table 6 and Figure 2). Accordingly, it can be concluded that the identified phytochemicals can serve as potential inhibitors for tumor progression.

Table 6. Free binding energies $(\Delta G)$ of the identified compounds within the PB1 active site calculated in $\mathrm{kcal} / \mathrm{mol}$ using Discovery Studio 4.5 adopting both rule-based and $\mathrm{pH}$-based ionization techniques.

\begin{tabular}{ccc}
\hline Compound & \multicolumn{2}{c}{ Binding Energy $\Delta \mathbf{G}$ (Kcal/mol) } \\
\cline { 2 - 3 } & Rule-based & pH-based \\
\hline Luteolin (LU2) & -35.58 & -35.58 \\
Malic acid (1) & -22.80 & -22.80 \\
Cinnamic acid (2) & -22.16 & -22.16 \\
Protocatechuic acid (3) & -22.52 & -27.03 \\
Chlorogenic acid (4) & -34.63 & -37.35 \\
Quinic acid (6) & -23.99 & -23.99 \\
1-O-Caffeoyl quinic acid (7 or 8) & -41.14 & -36.80 \\
4-O-Caffeoyl quinic acid (7 or 8) & -35.94 & -40.48 \\
3-Feruloyl quinic acid (10 or 12) & -44.29 & -38.26 \\
Caffeic acid (11) & -28.83 & -26.33 \\
5-Feruloyl quinic acid ((10 or 12) & -44.70 & -37.76 \\
Sinapic acid (13) & -33.58 & -28.39 \\
Dicaffeoyl quinic acid (17 or 19) & -50.49 & -49.04 \\
Kaempferol-O-rutinoside (18) & -43.79 & -53.74 \\
Rutin (20) & -41.21 & -50.12 \\
Quercetin-O-hexoside (21) & -48.53 & -49.53 \\
Isorhamnetin-O-rutinoside (22) & -36.76 & -52.02 \\
\hline
\end{tabular}


A

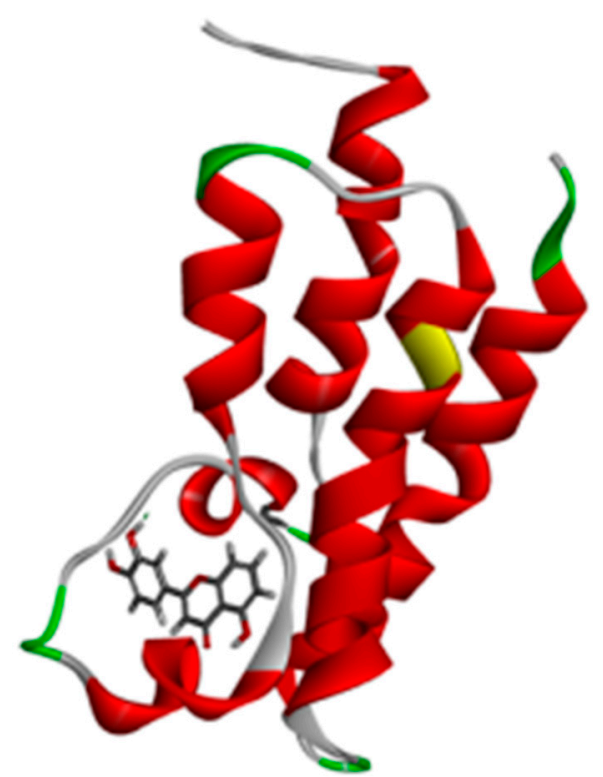

B
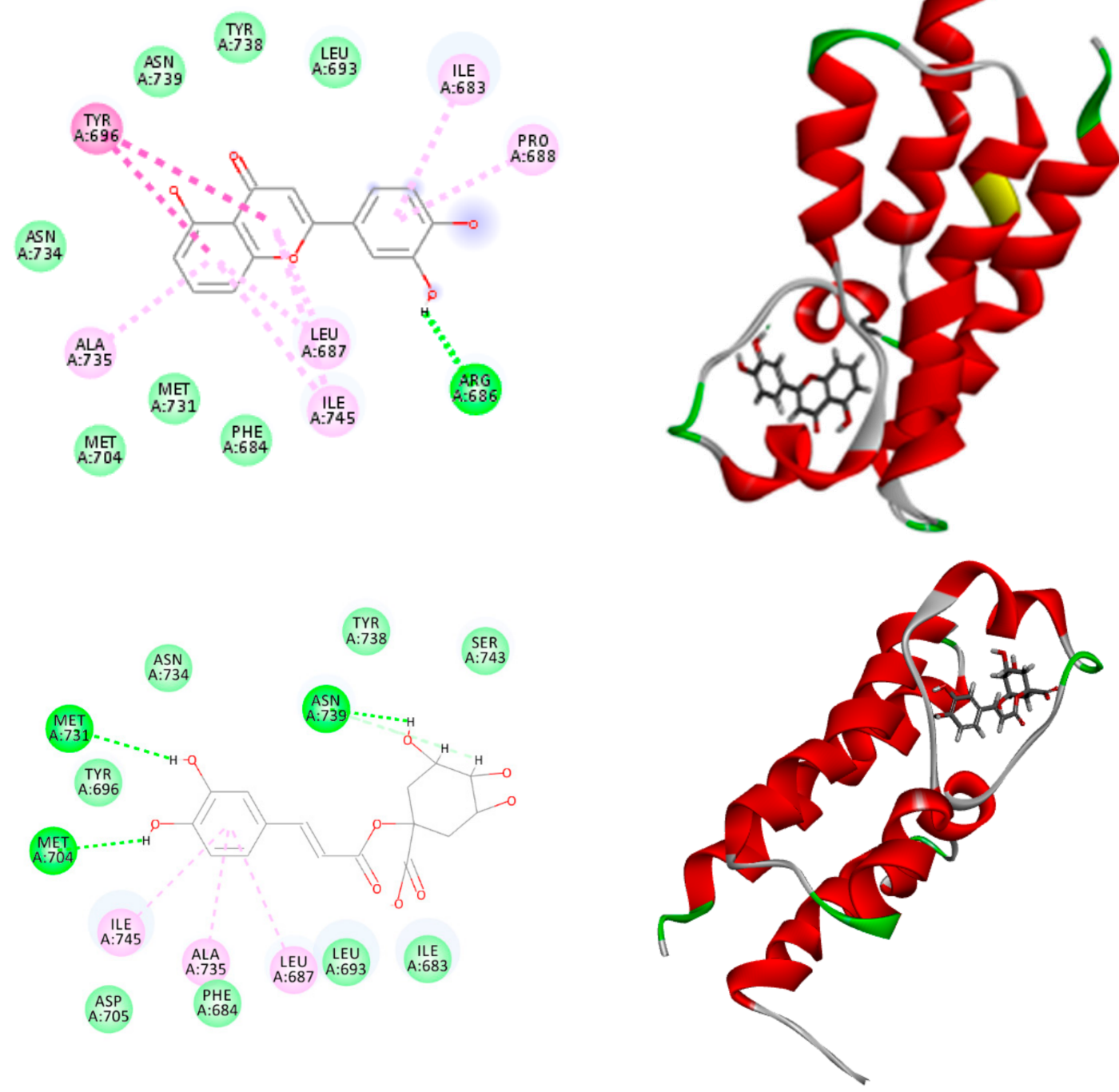

C
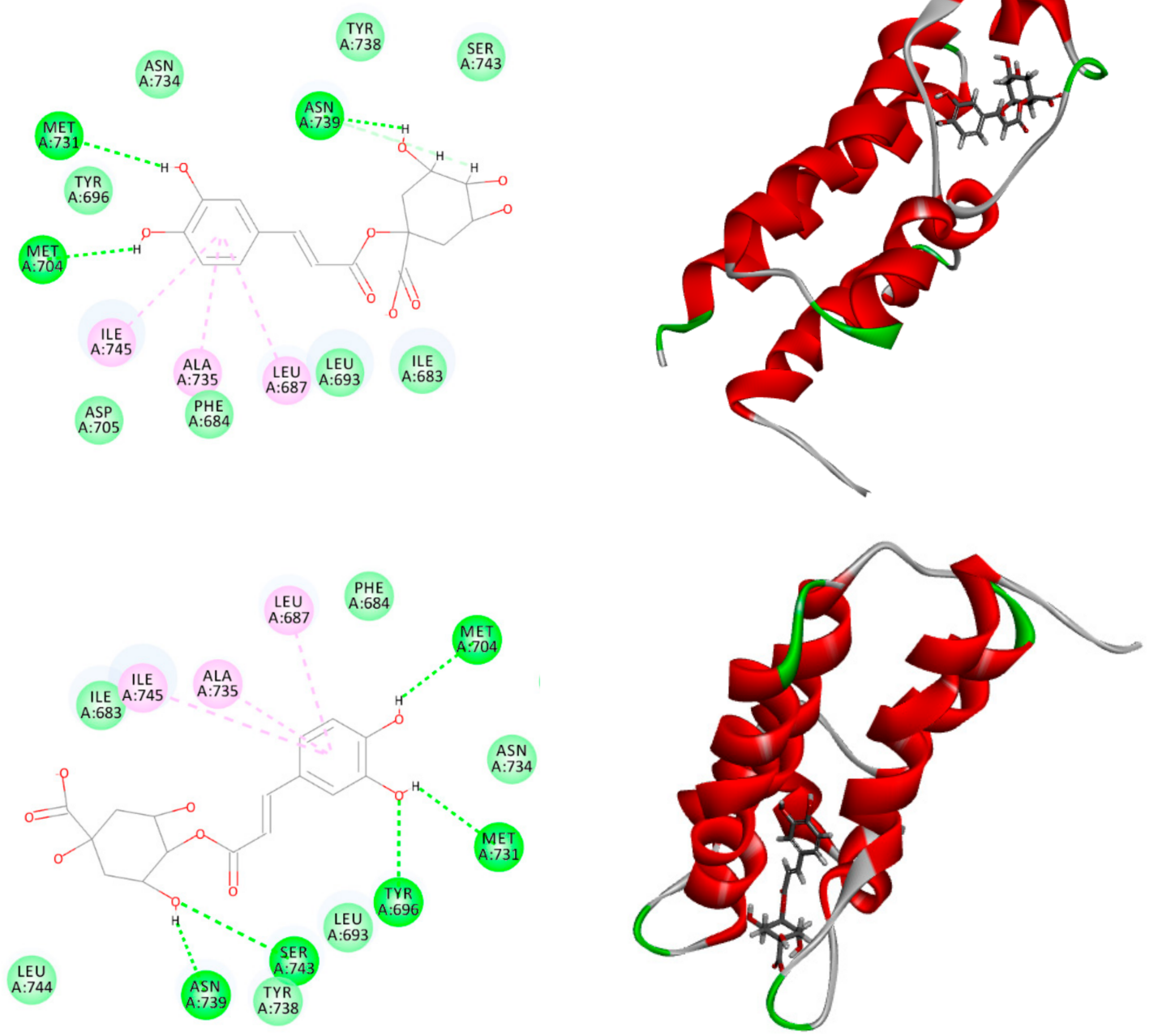

Figure 2. Cont. 
D
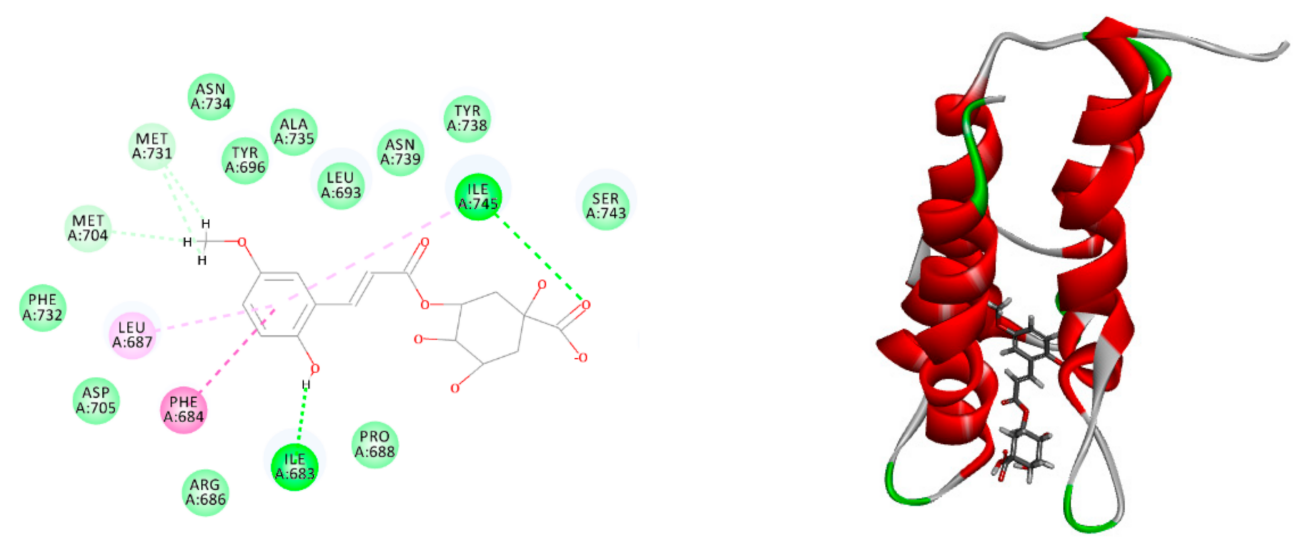

E
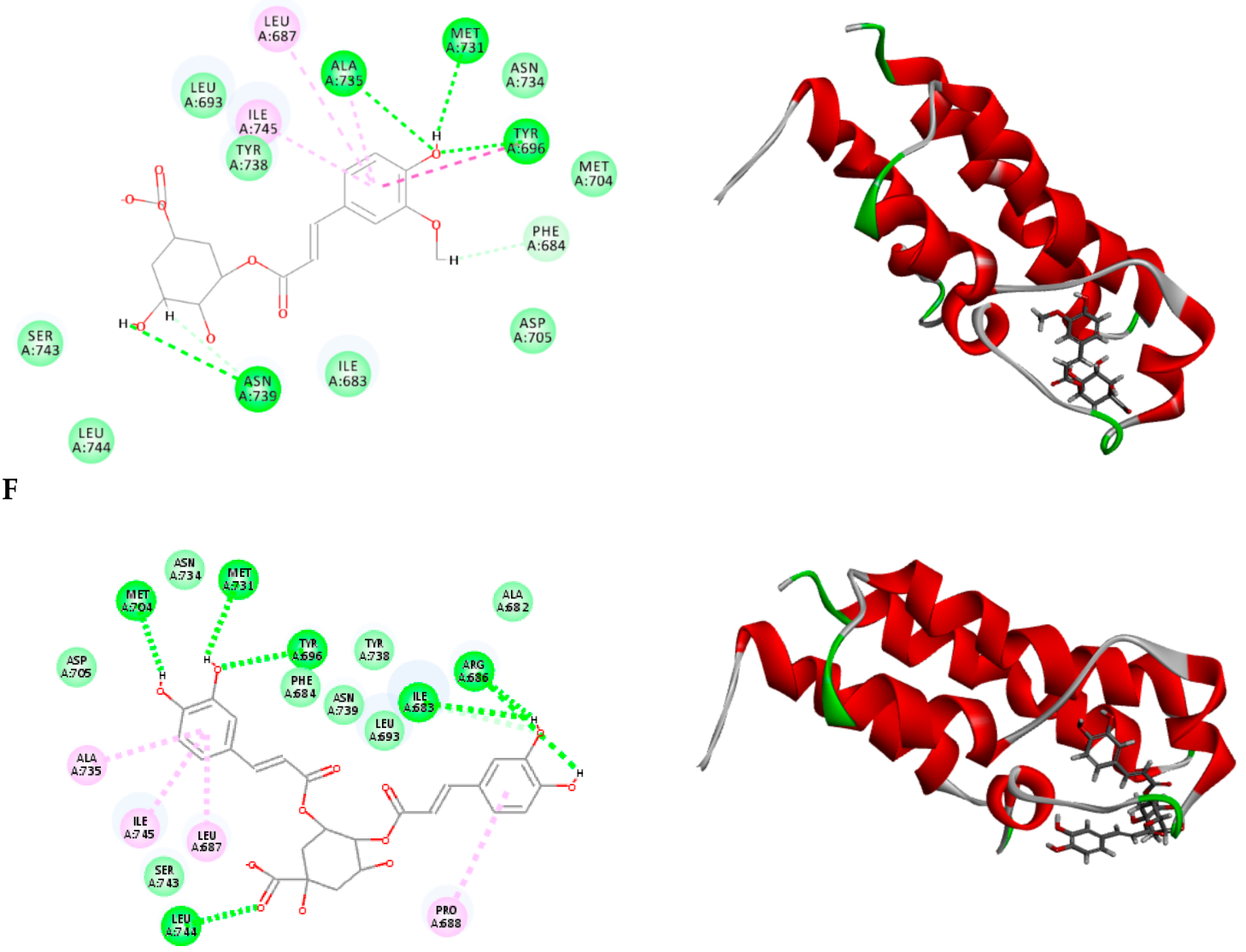

G

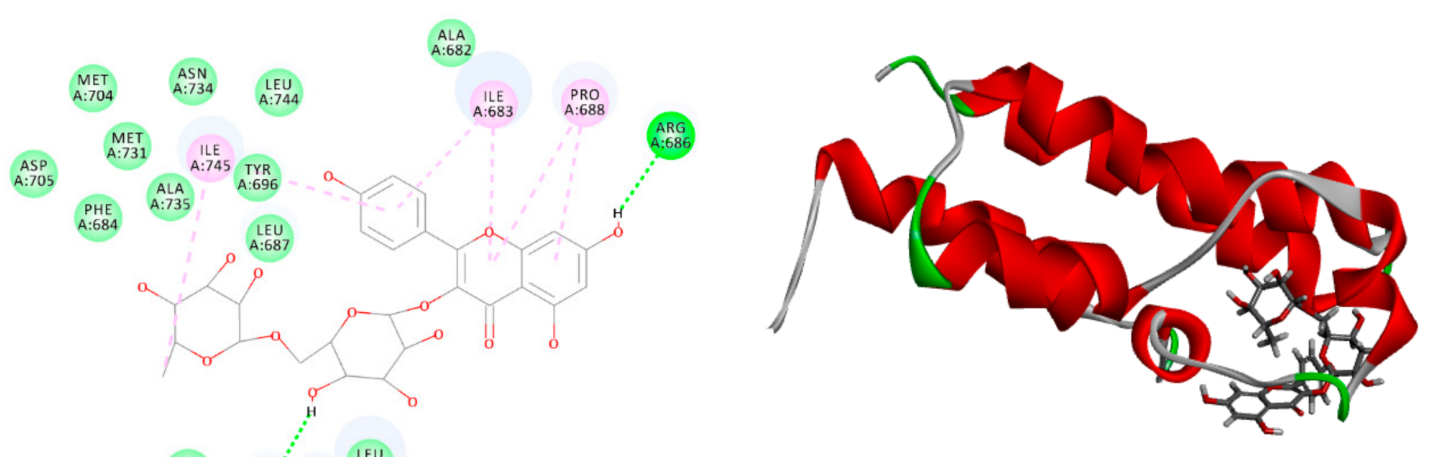

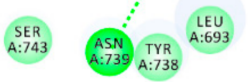

Figure 2. Cont. 
$\mathbf{H}$
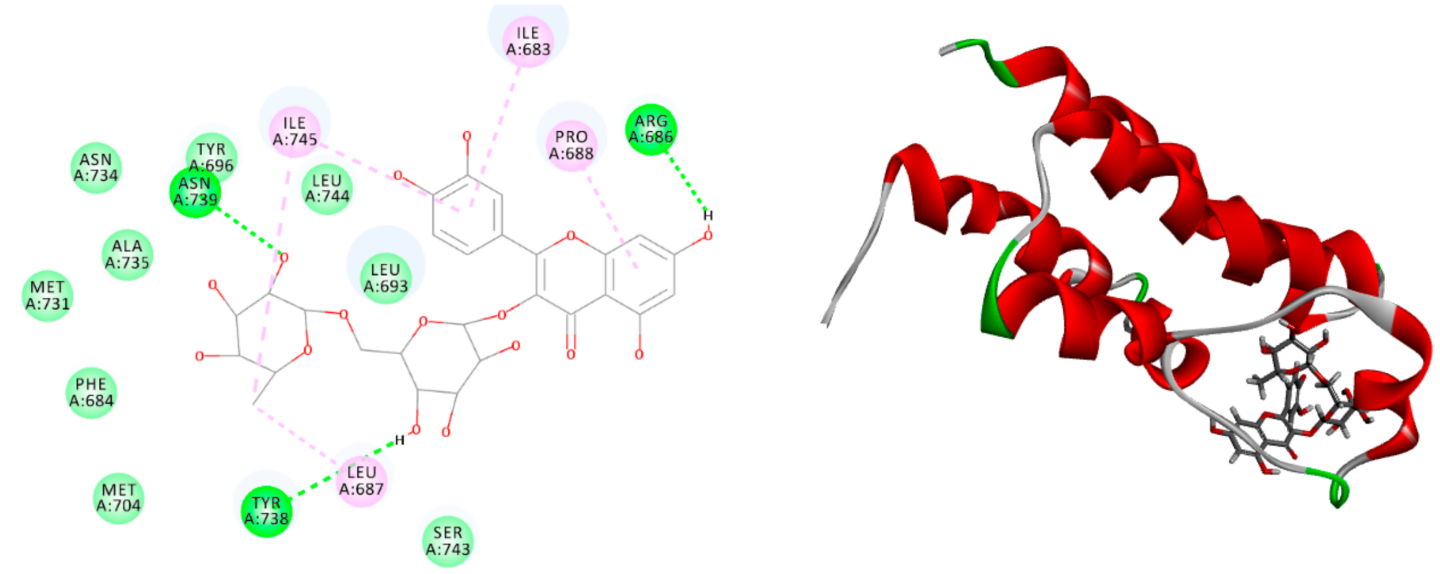

I
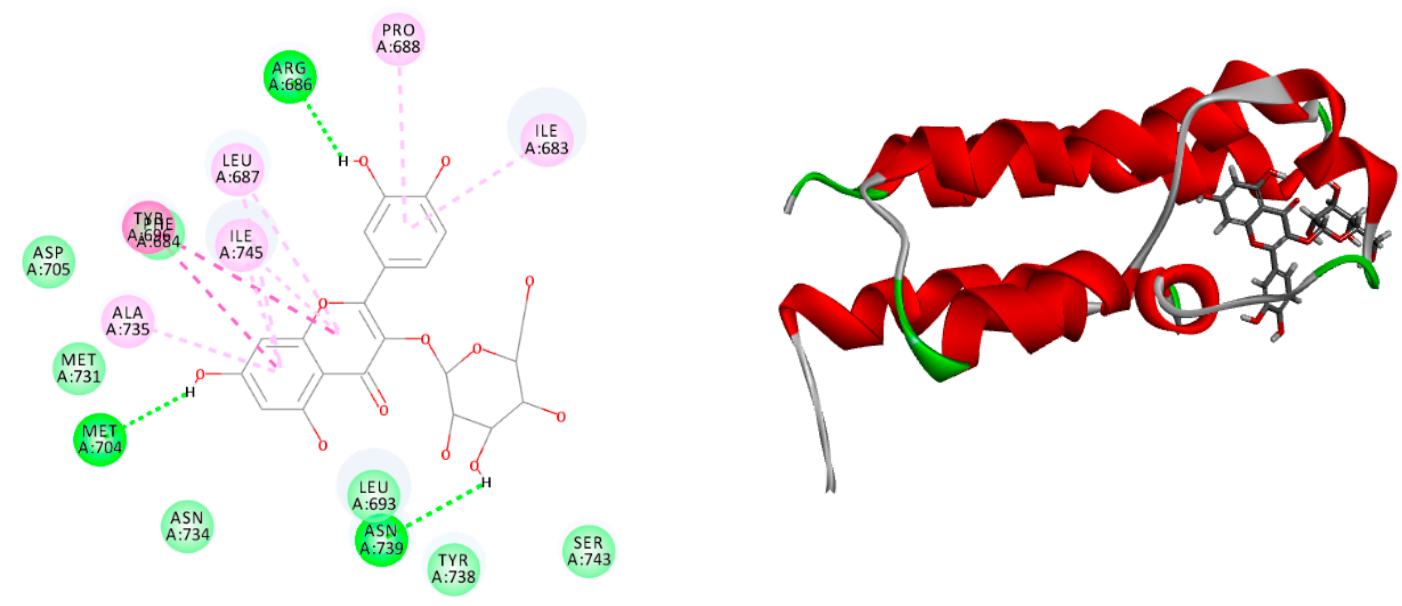

J
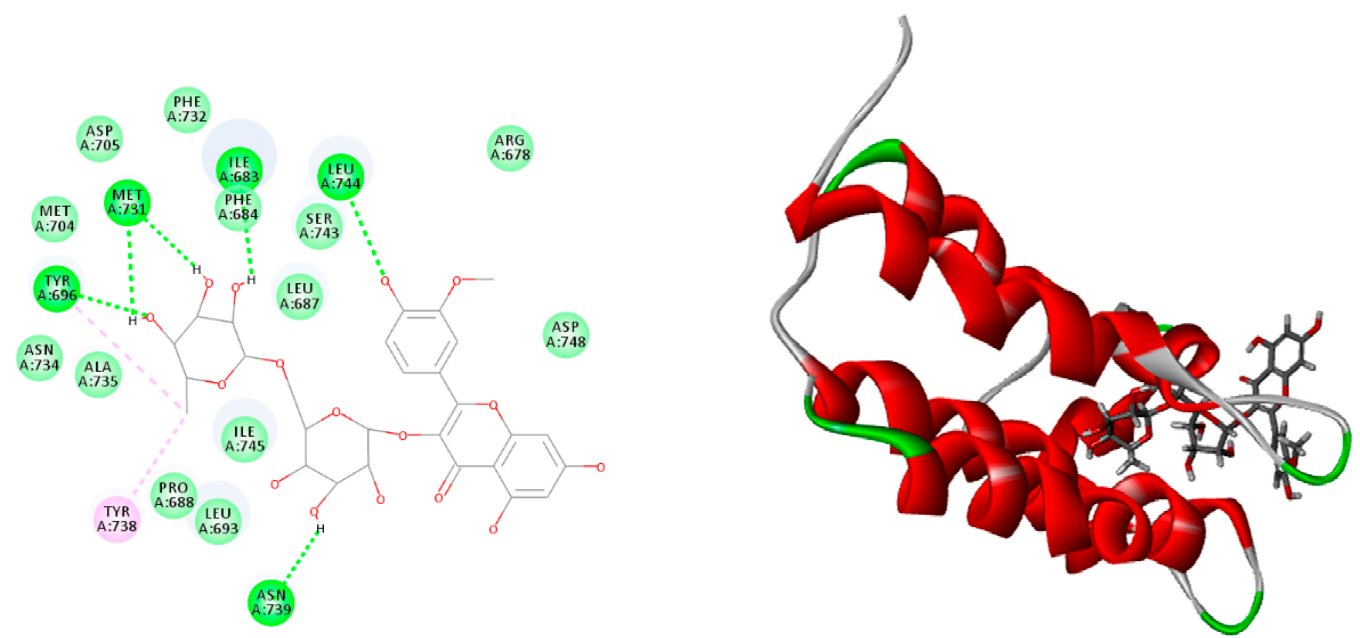

Figure 2. 2D and 3D ligand-enzyme interactions of high score compounds: (A) Luteolin (LU2), the co-crystallized inhibitor; (B) 1-O-Caffeoyl quinic acid (7); (C) 4-O-Caffeoyl quinic acid (8); (D) 3-Feruloyl quinic acid (10); (E) 5-Feruloyl quinic acid (12); (F)3,4-Dicaffeoyl quinic acid (17); (G) Kaempferol-O-rutinoside (18); (H) Rutin (20); (I) Quercetin-O-hexoside (21); (J) Isorhamnetin-O-rutinoside (22); with PB1 (PDB ID: 5II2). Residues are annotated with three-letter amino acid code and their position. Polar residues are coloured green; hydrophobic residues are coloured purple, Hydrogen-bonding interactions are represented with a green dashed line between the receptor and the ligand while $\pi$-alkyl interactions are represented with a purple dashed line. 


\section{Materials and Methods}

\subsection{Chemicals and Reagents}

Folin Ciocalteu reagent was obtained from Sigma-Aldrich (St Louis, MO, USA). Reference standards of gallic acid and quercetin were obtained from Sigma-Aldrich (St Louis, MO, USA). Aluminium chloride, was supplied by Al-Nasr Co., Egypt. MTT [3-(4,5-dimethylthiazol-2-yl)-2,5-diphenyltetrazolium bromide) which was purchased from Sigma-Aldrich (Munich, Germany). All other reagents and media were purchased from Invitrogen (Karlsruhe, Germany). Solvents were purchased from Sigma-Aldrich (Munich, Germany).

\subsection{Plant Material}

E. pectinatus flower heads were collected in January 2017, from a public garden in Cairo, Egypt. The plant material was authenticated by Dr. Mohamed El-Gibaly, Professor of Taxonomy and Consultant for Central Administration of Plantation and Environment, Cairo, Egypt. A voucher specimen (PHG-EP-116) has been deposited in the Pharmacognosy Department, Faculty of Pharmacy, Future University in Egypt, New Cairo, Egypt.

\subsection{Preparation of Plant Extract}

Air-dried flower heads (480 g) were coarsely powdered and exhaustively extracted with $70 \%$ aqueous methanol $(4 \mathrm{~L} \times 6)$. The residue left after evaporation of the solvent $(90.36 \mathrm{~g})$ was defatted with dichloromethane under reflux $\left(1 \mathrm{~L} \times 5,50{ }^{\circ} \mathrm{C}\right)$ to yield $3.20 \mathrm{~g}$ of the dichloromethane fraction and $85.63 \mathrm{~g}$ of the defatted methanol fraction (EP-MF) which was kept in a tight container at $4{ }^{\circ} \mathrm{C}$ for further analysis.

\subsection{Phytochemical Analysis}

\subsubsection{Quantitation of Total Flavonoids}

A spectrophotometric method was conducted using $\mathrm{AlCl}_{3}$ complex method [23] Quercetin was used as a reference standard. The assay was performed in triplicate. The total flavonoid content was determined from the calibration curve and expressed as $\mu \mathrm{g}$ quercetin equivalent $(\mathrm{QE}) / \mathrm{mg}$ dried flower extract.

\subsubsection{Quantitation of Total Phenolic Compounds}

A spectrophotometric method was adopted using the Folin Ciocalteu colourimetric method [24]. Gallic acid was used as a reference standard. The assay was performed in triplicate. The total phenolic content was calculated as $\mu \mathrm{g}$ gallic acid equivalent (GAE)/mg dried flower extract.

\subsubsection{HPLC-PDA-ESI-MS/MS Analysis}

HPLC-PDA-ESI-MS/MS analysis was performed on a Finnigan LCQ-Duo ion trap mass spectrometer with an ESI source (ThermoQuest) coupled to a Finnigan Surveyor HPLC system (MS pump plus, autosampler, and PDA detector plus) with a EC 150/3 Nucleodur 100-3, reversed phase C18 column (Macherey-Nagel). A gradient of water and acetonitrile (ACN) with $0.1 \%$ formic acid (ESI-) and without (ESI+) was applied from 2 to $100 \% \mathrm{ACN}$ in $60 \mathrm{~min}$ at $30{ }^{\circ} \mathrm{C}$. The flow rate was $0.5 \mathrm{~mL} / \mathrm{min}$. The injection volume was $20 \mu \mathrm{L}$. All samples were measured in the positive and negative ion modes. The MS was operated with a capillary voltage of $10 \mathrm{~V}$, source temperature of $240{ }^{\circ} \mathrm{C}$, and high purity nitrogen as a sheath and auxiliary gas at a flow rate of 80 and 40 (arbitrary units), respectively. The ions were detected in a mass range of 50-2000 m/z. Collision energy of $35 \mathrm{eV}$ was used in MS/MS for fragmentation. Data acquisitions and analyses were executed by XcaliburTM 2.0.7 software (Thermo Scientific). 


\subsection{Biological Activity}

\subsubsection{Cytotoxicity and Cell Proliferation Assays}

\section{Cell Culture}

Six different human tumor cell lines were used including liver (HepG2), breast (MCF-7), lung (A549), colon (Caco2 and HCT-116) as well as acute lymphocytic leukemia (CCRF-CEM, CEM/ADR5000. All cell lines were obtained from American type cell culture collection (ATCC, Manassas, VA, USA) except Human colon adenocarcinoma; Caco-2 (wild type) cells were a gift from Prof. Dr. Gert Fricker, Institute of Pharmacy and Molecular Biotechnology, University of Heidelberg, Heidelberg, Germany. The cells were originally obtained from a 72-year old Caucasian suffering from colon adenocarcinoma (according to the American Type Culture Collection, Rockville, MD, USA). Additionally, Human leukaemia cell lines CCRF-CEM and CEM/ADR5000 cells were obtained from Dr. Axel Sauerbrey, Department of Pediatrics, University of Jena, Jena, Germany. Cells were originally obtained from a 4-year Caucasian female suffering from acute lymphoblastic leukemia.

\section{Assessment of Cytotoxicity Using MTT Assay}

EP-MF anti-proliferative activity was investigated using MTT assay [25]. Cell lines were suspended in RPMI 1640 medium in Corning ${ }^{\circledR}$ 96-well tissue culture plates, and then incubated for $24 \mathrm{~h}$. The tested extract was then added into 96-well plates (six replicates) to achieve eight concentrations for each group. Six vehicle controls with media were run for each 96 well plate as a control. After incubating for $48 \mathrm{~h}$, the number of viable cells were determined using MTT assay. Briefly, the media were removed and replaced with $100 \mu \mathrm{L}$ of fresh culture RPMI 1640 medium then $10 \mu \mathrm{L}$ of $12 \mathrm{mM}$ MTT stock solution (5 mg of MTT in $1 \mathrm{~mL}$ of PBS) were added to each well and cells were allowed to metabolize the dye into a colored insoluble formazan crystal for $2 \mathrm{~h}$. The remaining MTT solution was discarded from the wells and the formazan crystals produced by viable cells were dissolved in $200 \mu \mathrm{L} /$ well acidified isopropanol for $30 \mathrm{~min}$, then, were covered with aluminum foil and shaken continuously using a MaxQ 2000 plate shaker (Thermo Fisher Scientific Inc, Kalamazoo, MI, USA) at room temperature. Absorbance was measured at $570 \mathrm{~nm}$ using a microplate reader (SunRise, TECAN, Inc, Morrisville, NC, USA). The cell viability was expressed as percentage of the control. The concentration that induces $50 \%$ of maximum inhibition of cell proliferation $\left(\mathrm{IC}_{50}\right)$ was determined using Graph Pad Prism version 5 (San Diego, CA, USA).

\section{Assessment of $\mathrm{IC}_{50}$ and Relative Resistance Values of Doxorubicin and E. pectinatus}

This study was designed to evaluate the $\mathrm{IC}_{50}$ and relative resistance of multidrug-resistant MCF-7/Dox, CEM/ADR5000 leukemia and Caco-2 monolayer cells for EP-MF and doxorubicin. MCF-7/Dox and CEM/ADR5000 cells (overexpressing P-gp) were seeded at a density of $5 \times 10^{4}$ cells per well into 96-well plates, whereas, Caco- 2 cells were seeded at a density of $2 \times 10^{4}$ cells per well. $\mathrm{IC}_{50}$ was determined $72 \mathrm{~h}$ post-incubation using MTT assay [25]. Each concentration was processed six times, and the corresponding $\mathrm{IC}_{50}$ value was calculated from a sample size of 3 runs.

Effects of E. pectinatus on Doxorubicin Cytotoxicity

MCF-7/Dox, CEM/ADR5000 cells were seeded at a density of $5 \times 10^{4}$ cells per well into 96-well plates and initially incubated with non-toxic doses of EP-MF $(5 \mu \mathrm{g} / \mathrm{mL})$ for $6 \mathrm{~h}$, followed by serial dilutions of doxorubicin $(0.1-50 \mu \mathrm{M})$. Caco-2 cells were seeded at a density of $2 \times 10^{4}$ cells per well and initially incubated with non-toxic doses of EP-MF $(5 \mu \mathrm{g} / \mathrm{mL})$ for $6 \mathrm{~h}$, followed thereafter by serial dilutions of doxorubicin $(0.01-20 \mu \mathrm{M})$. The cell viability was determined $72 \mathrm{~h}$ post-incubation using MTT assay. 


\subsubsection{Effects of E. pectinatus on P-glycoprotein}

To unravel a potential action of EP-MF on P-gp, the following assays were performed using fluorescent P-gp substrates.

Assessment of P-glycoprotein Activity via Calcein-AM Assay Using Flow Cytometric Technique

For flow cytometry-based Calcein-AM assay, the cells (MCF-7/Dox, CEM/ADR5000) at a density of $2.5 \times 10^{7}$ cells per well were short-term incubated with non-toxic serial dilutions of EP-MF $(0.5-10 \mu \mathrm{g} / \mathrm{mL})$. Calcein was added to a final concentration of $1 \mu \mathrm{M}$ for $30 \mathrm{~min}$ at $37^{\circ} \mathrm{C}$. The intracellular fluorescence was measured using a fluorescence-activated cell sorting system (FACS). Verapamil was used as a positive control.

\section{Calcein-AM Assay Using a Fluoroskan Ascent Plate Reader}

Caco-2 monolayers were incubated with non-toxic concentrations of EP-MF $(0.1-10 \mu \mathrm{g} / \mathrm{mL})$ for $2 \mathrm{~h}$ at $37^{\circ} \mathrm{C}$. Subsequently, Calcein-AM was added to a final concentration of $1 \mu \mathrm{M}$ for $30 \mathrm{~min}$ at $37^{\circ} \mathrm{C}$. The fluorescence was measured using a Fluoroskan Ascent ${ }^{\circledR}$ plate reader (Microplate reader (SunRise, TECAN, Inc., USA). The fluorescence was detected at $\lambda$ (excitation) $=485 \mathrm{~nm}$ and $\lambda$ (emission) $=520 \mathrm{~nm}$. Each concentration of the tested extract was measured. The intracellular fluorescence was obtained by subtracting the background fluorescence of control wells and Calcein uptake was expressed as \% of control. Verapamil served as a positive control.

\subsection{Molecular Docking}

The probable molecular binding mode between the identified compounds and fifth bromodomain of human polybromo-1 (PB1) was evaluated using the CDOCKER algorithm in Discovery Studio 4.5 (Accelrys Software, Inc., San Diego, CA, USA). Bromodomains (BRDs) are epigenetic interaction domains currently recognized as emerging drug targets for the development of anticancer agents [26]. The crystal structure of BRDs (PDB ID: 5II2) was retrieved from the Protein Data Bank (http:// www.rcsb.org/pdb/). Water molecules in the protein were removed, and the protein was refined. The co-crystallized ligand $5 \mathrm{II} 2$ was used as the positive control ligand, and the binding site was defined based on the binding of the co-crystallized inhibitor and PB1. Prior to docking, the co-crystallized ligand was removed; then, the prepared ligands were docked into the protein binding site implementing rule-based and $\mathrm{pH}$-based ionization methods, using appropriate parameters. The interaction energy was calculated to analyze the interaction between the ligand and the receptor. For each ligand, the top 10 ligand-binding poses were ranked according to their CDOCKER energies, and the predicted binding interactions were analyzed, from which the best ligand-binding poses were chosen. Validation of CDOCKER as a docking algorithm for PB1 was achieved by calculating the root-mean-square deviations (RMSD) after redocking the co-crystallized ligand to the protein structure using the algorithm as previously described [27]. To evaluate the possible interactions between the isolated compounds and PB1 proposed binding sites and molecular docking studies were performed using the CDOCKER algorithm within Discovery Studio 4.5.

\section{Conclusions}

In this study, a flower extract from E. pectinatus exhibited moderate cytotoxic effect against six types of cancer cell lines. The extract could inhibit P-gp comparable to verapamil and could resensitize MDR cells when applied in combination with doxorubicin. This effect can be attributed to the flavonoid content of E. pectinatus. Furthermore, the identified phytochemicals showed promising inhibitory activity to PB1 protein evaluated using in silico molecular docking, thus, can serve as potential inhibitors for tumor progression. The use of E. pectinatus extract alone or in combination with conventional chemotherapy might be an interesting candidate as an adjuvant drug in cancer therapy, provided more studies are conducted to determine the in vivo efficacy. 
Supplementary Materials: The following figures are available online: ESI-MS/MS spectra of selected compounds identified in E. pectinatus flower extract.

Author Contributions: W.M.E. prepared the plant extract, designed the phytochemistry work, performed the total phenolics and flavonoids assays, interpreted LC/MS data, performed the molecular docking and wrote the manuscript. I.M.A. designed the phytochemistry work, interpreted LC/MS data, revised the molecular docking and wrote the manuscript. Y.A.-M. designed and performed the cytotoxicity assays, analyzed the data and wrote the manuscript. M.F.E. designed and performed the cytotoxicity assays, analyzed the data, wrote the manuscript. M.W. supervised the work, and revised the manuscript. All authors have read and agreed to the published version of the manuscript.

Funding: The research was funded by Deutsche Forschungsgemeinschaft and Ruprecht-Karls-Universität Heidelberg within the funding program Open Access Publishing.

Acknowledgments: The authors are grateful to Bernhard Wetterauer (IPMB) for conducting HPLC-PDA-ESI-MS/MS analysis in Institute of Pharmacy and Molecular Biotechnology, Heidelberg University, Heidelberg, Germany. Iriny M. Ayoub acknowledges the Science and Technology Development Fund in Egypt (STDF, project ID 25448) for funding the postdoctoral fellowship in Heidelberg, Germany.

Conflicts of Interest: The authors declare there is no conflict of interest.

\section{Abbreviations}

\section{HPLC-PDA-ESI-MS}

\section{E. pectinatus}

EP-MF

HepG2

Caco-2

MCF7

A549

HCT 116

CCRF-CEM

MTT

MDR

P-gp

ABC

PB1

BRDs
High performance liquid chromatography-photodiode array-electrospray ionization-mass spectrometry

Euryops pectinatus

Euryops pectinatus defatted methanol fraction liver hepatocellular carcinoma cell line colon carcinoma cell line breast cancer cell line lung cancer cell line colon cancer cell line acute lymphocytic leukemia cell line 3-(4,5-Dimethylthiazol-2-yl)-2,5-diphenyltetrazolium bromide multidrug resistance P-glycoprotein ATP-binding cassette human polybromo-1 Bromodomains

\section{References}

1. Persidis, A. Cancer multidrug resistance. Nat. Biotechnol. 1999, 17, 94. [CrossRef]

2. Karthikeyan, S.; Hoti, S.L. Development of fourth generation ABC inhibitors from natural products: A novel approach to overcome cancer multidrug resistance. Anti-Cancer Agents Med. Chem. 2015, 15, 605-615. [CrossRef] [PubMed]

3. Mohana, S.; Ganesan, M.; Agilan, B.; Karthikeyan, R.; Srithar, G.; Beaulah Mary, R.; Ananthakrishnan, D.; Velmurugan, D.; Rajendra Prasad, N.; Ambudkar, S.V. Screening dietary flavonoids for the reversal of P-glycoprotein-mediated multidrug resistance in cancer. Mol. Biosyst. 2016, 12, 2458-2470. [CrossRef] [PubMed]

4. Elkady, W.M.; Ayoub, I.M. Chemical profiling and antiproliferative effect of essential oils of two Araucaria species cultivated in Egypt. Ind. Crops Prod. 2018, 118, 188-195. [CrossRef]

5. Jackson, W.P.U. Origins and Meanings of Names of South African Plant Genera; University of Cape Town: Cape Town, South Africa, 1990.

6. Hafez, E.; Paulis, M.; Ahmed, M.; Fathy, M.N.; Abdel-Lateff, A.; Algandaby, M. Protective and anti-oxidant activity of the Euryops arabicus against paracetamol induced hepatorenal toxicity in rats. J. Toxicol. Clin. 2015, 5. [CrossRef]

7. Mothana, R.A.; Alsaid, M.S.; Al-Musayeib, N.M. Phytochemical analysis and in vitro antimicrobial and free-radical-scavenging activities of the essential oils from Euryops arabicus and Laggera decurrens. Molecules 2011, 16, 5149-5158. [CrossRef] [PubMed] 
8. Nesseem, D.I.; Michel, C.G. Development and characterization of local anti-inflammatory implantation for the controlled release of the hexane extract of the flower-heads of Euryops pectinatus L. (Cass.). Drug Discov. Ther. 2011, 5, 96-106. [CrossRef]

9. Michel, C.G. Essential oil and morphological characters of leaves of Euryops pectinatus (L.) Cass. cultivated in Egypt. Bull. Fac. Pharm. Cairo Univ. 2004, 42, 145-158.

10. Catarino, M.D.; Silva, A.M.S.; Saraiva, S.C.; Sobral, A.J.F.N.; Cardoso, S.M. Characterization of phenolic constituents and evaluation of antioxidant properties of leaves and stems of Eriocephalus africanus. Arab. J. Chem. 2018, 11, 62-69. [CrossRef]

11. Simirgiotis, M.; Benites, J.; Areche, C.; Sepúlveda, B. Antioxidant capacities and analysis of phenolic compounds in three endemic Nolana species by HPLC-PDA-ESI-MS. Molecules 2015, 20, 11490-11507. [CrossRef]

12. Clifford, M.N.; Wu, W.; Kirkpatrick, J.; Kuhnert, N. Profiling the chlorogenic acids and other caffeic acid derivatives of herbal Chrysanthemum by LC-MS ${ }^{n}$. J. Agric. Food. Chem. 2007, 55, 929-936. [CrossRef] [PubMed]

13. Chen, H.J.; Inbaraj, B.S.; Chen, B.H. Determination of phenolic acids and flavonoids in Taraxacum formosanum Kitam by liquid chromatography-tandem mass spectrometry coupled with a post-column derivatization technique. Int. J. Mol. Sci. 2012, 13, 260-285. [CrossRef] [PubMed]

14. Kenny, O.; Smyth, T.J.; Walsh, D.; Kelleher, C.T.; Hewage, C.M.; Brunton, N.P. Investigating the potential of under-utilised plants from the Asteraceae family as a source of natural antimicrobial and antioxidant extracts. Food Chem. 2014, 161, 79-86. [CrossRef] [PubMed]

15. Engels, C.; Schieber, A.; Glanzle, M.G. Sinapic acid derivatives in defatted Oriental mustard (Brassica juncea L.) seed meal extracts using UHPLC-DAD-ESI-MS ${ }^{n}$ and identification of compounds with antibacterial activity. Eur. Food Res. Technol. 2012, 234, 535-542. [CrossRef]

16. Farag, M.A.; Sakna, S.T.; El-fiky, N.M.; Shabana, M.M.; Wessjohann, L.A. Phytochemical, antioxidant and antidiabetic evaluation of eight Bauhinia L. species from Egypt using UHPLC-PDA-qTOF-MS and chemometrics. Phytochemistry 2015, 119, 41-50. [CrossRef]

17. Farag, M.A.; El-Ahmady, S.H.; Elian, F.S.; Wessjohann, L.A. Metabolomics driven analysis of artichoke leaf and its commercial products via UHPLC-q-TOF-MS and chemometrics. Phytochemistry 2013, 95, 177-187. [CrossRef]

18. De Nisco, M.; Manfra, M.; Bolognese, A.; Sofo, A.; Scopa, A.; Tenore, G.C.; Pagano, F.; Milite, C.; Russo, M.T. Nutraceutical properties and polyphenolic profile of berry skin and wine of Vitis vinifera L. (cv. Aglianico). Food Chem. 2013, 140, 623-629. [CrossRef]

19. Djoukeng, J.D.; Arbona, V.; Argamasilla, R.; Gomez-Cadenas, A. Flavonoid profiling in leaves of Citrus genotypes under different environmental situations. J. Agric. Food. Chem. 2008, 56, 11087-11097. [CrossRef]

20. Lusa, M.G.; Martucci, M.E.; Loeuille, B.F.; Gobbo-Neto, L.; Appezzato-da-Glória, B.; Da Costa, F.B. Characterization and evolution of secondary metabolites in Brazilian Vernonieae (Asteraceae) assessed by LC-MS fingerprinting. J. Linn. Soc. Lond. Bot. 2016, 182, 594-611. [CrossRef]

21. Bai, J.; Zhao, S.; Fan, X.; Chen, Y.; Zou, X.; Hu, M.; Wang, B.; Jin, J.; Wang, X.; Hu, J.; et al. Inhibitory effects of flavonoids on P-glycoprotein in vitro and in vivo: Food/herb-drug interactions and structure-activity relationships. Toxicol. Appl. Pharmacol. 2019, 369, 49-59. [CrossRef]

22. Myrianthopoulos, V.; Gaboriaud-Kolar, N.; Tallant, C.; Hall, M.-L.; Grigoriou, S.; Brownlee, P.M.; Fedorov, O.; Rogers, C.; Heidenreich, D.; Wanior, M. Discovery and optimization of a selective ligand for the switch/sucrose nonfermenting-related bromodomains of polybromo protein-1 by the use of virtual screening and hydration analysis. J. Med. Chem. 2016, 59, 8787-8803. [CrossRef] [PubMed]

23. Piyanete, C.; Meechai, P.; Nakbanpotecc, W. Antioxidant activities and phenolic contents of extracts from Salvinia molesta and Eichornia crassipes. Res. J. Biol. Sci. 2009, 4, 1113-1117.

24. Kumazawa, S.; Tanguchi, M.; Suzuki, Y.; Shimura, M.; Kwon, MS.; Nakayama, T. Antioxidant activity of polyphenols in carob pods. J. Agric. Food. Chem. 2002, 50, 373-377. [CrossRef] [PubMed]

25. Mosmann, T. Rapid colorimetric assay for cellular growth and survival: Application to proliferation and cytotoxicity assays. J. Immunol. Meth. 1983, 65, 55-63. [CrossRef] 
26. Fujisawa, T.; Filppakopoulos, P. Functions of bromodomain-containing proteins and their roles in homeostasis and cancer. Nat. Rev. Mol. Cell Biol. 2017, 246. [CrossRef]

27. Ayoub, I.M.; Korinek, M.; Hwang, T.-L.; Chen, B.-H.; Chang, F.-R.; El-Shazly, M.; Singab, A.N.B. Probing the antiallergic and anti-inflammatory activity of biflavonoids and dihydroflavonols from Dietes bicolor. J. Nat. Prod. 2018. [CrossRef]

Sample Availability: Samples of the plant extract are available from the authors.

(C) 2020 by the authors. Licensee MDPI, Basel, Switzerland. This article is an open access article distributed under the terms and conditions of the Creative Commons Attribution (CC BY) license (http://creativecommons.org/licenses/by/4.0/). 